Turhan, H. ve Ak Başoğul, D. (2013). Orhan Kemal'in Avare Yıllar adlı romanı üzerine bir inceleme. Ana Dili Eğitimi Dergisi, 1(4), 38-50.

\begin{tabular}{ll}
\hline & $\begin{array}{l}\text { Ana Dili Eğitimi Dergisi } \\
\text { Journal of Mother Tongue Education } \\
\text { ADED - JOMTE } \\
\text { www.anadiliegitimi.com }\end{array}$ \\
\hline
\end{tabular}

\title{
Orhan Kemal'in Avare Yıllar Adlı Romanı Üzerine Bir İnceleme
}

\author{
Hatice Turhan ${ }^{*}$ \\ Duygu Ak Başoğul
}

\begin{abstract}
Özet
Edebiyat yapıtlarının incelenmesinin, yapıtların karanlıkta kalan yönlerinin aydınlatılmasında önemli bir işlevi vardır. Türk edebiyatının üretken yazarlarından biri olan Orhan Kemal'in Avare Yıllar adlı yapıtının incelenmesi de bu bağlamda önemlidir. Küçük Adamın Notları serisinin ikinci kitabı olan Avare Yıllar, yazarın gençlik dönemindeki yaşantısı ile benzerlikler göstermektedir. Yokluk içerisindeki gençlerin yaşam karşısında ürettiği çözümleri özgün bir kurguyla aktarması açısından incelenmesi gereken bir yapıttır. Bu çalışmada, Avare Yıllar adlı yapıt roman kurgusu, karakterler, teknik, dil ve anlatım açısından incelenmiştir. Betimsel nitelikte olan bu araştırma doküman analizi yöntemi ile yapılmıştır. Yapılan inceleme sonucunda işçi sınıfının ve yoksul gençlerin sorunlarının başarılı bir kurgu içerisinde yalın bir dille, halk deyişlerine yer verilerek sunulduğu görülmüştür.
\end{abstract}

Anahtar Sözcükler: Orhan Kemal, Avare Yıllar, Toplumsal Gerçekçilik

\section{An Examination on Orhan Kemal's Novel: Avare Yıllar}

\begin{abstract}
The examination of literary works has an important role to enlighten the dark sides of these works. In this aspect, the examination of Avare Yıllar written by Orhan Kemal who is the creative writers of Turkish Literature is really important. As being the second book of the Küçük Adamın Notları series, Avare Yıllar has similarities with the early years of the writer. It has to be examined because of the peculiar expression about the poor young people and their struggle with the life. In this study the novel has been examined on setting, characters, technique, language and expression. This descriptive research has been done by the document analysis method. At the end of the examination, the problems of proletariat and poor young people have been presented in a successful setting, by simple language and placing folk wisdom.
\end{abstract}

Key Words: Orhan Kemal, Avare Yıllar, Social Realism

\footnotetext{
*Öğr., MEB, İstanbul; Ankara Üniversitesi, Eğitim Bilimleri Enstitüsü, Eğitimin Kültürel Temelleri Anabilim Dalı, Güzel Sanatlar Eğitimi Bilim Dalı, Türkçe Eğitimi Doktora Programı Öğrencisi.

E-posta: haticeeturhan@gmail.com

** Öğr. Gör., Ankara Üniversitesi TÖMER, İstanbul; Marmara Üniversitesi, Eğitim Bilimleri Enstitüsü, Türkçe Eğitimi Anabilim Dalı, Türkçe Öğretmenliği Doktora Programı Öğrencisi.

E-posta: duyguakbasogul@gmail.com
} 


\section{Giriş}

Asıl adı Mehmet Raşit Öğütçü olan Orhan Kemal, 15 Eylül 1914'te Adana'nın Ceyhan ilçesinde doğdu. Babası, 1920-1923 döneminde birinci TBMM'de milletvekilliği, 3 Mayıs 1920'de Vekiller Heyeti'nde Adliye Bakanlığı yapan ve 26 Eylül 1930'da Adana'da Ahali Cumhuriyet Fırkası'nı kuran Abdülkadir Kemali Bey'dir.

Babası çıkardığı Ahali adlı gazetede hükümete muhalefet edince baskı göreceğini anlayarak Suriye'ye kaçmış, oradan da Lübnan'a geçmiştir. İlkokul üçüncü sınıfta babasının yanına Beyrut'a giden, onunla birlikte sürgün hayatı yaşayan Orhan Kemal, bir dönem basımevinde çalışır. Bu dönemi Baba Evi romanında anlatmıştır. Sonrasında Adana'ya dönen yazar yeniden okula gitmemeye başlar. Bir süre başıboş bir yaşam sürer daha sonra bir pamuk fabrikasında çok küçük bir ücretle kâtiplik, ambar memurluğu yapar. Yaşamının bu dönemlerini Avare Yıllar adlı romanında anlatır. Bir tüccarın önerdiği hileli işi kabul etmeyince iftiraya uğrayarak işten çıkarııır, ardından askere alınır. Bir ihbar üzerine Nazım Hikmet kitapları okuduğu gerekçesiyle beş yıl hapis cezası alır. Kayseri, Adana, Bursa cezaevlerinde kalır. Bursa cezaevinde Nazım Hikmet'in yardımıyla, kültür ve sanat bilgisini geliştirir. Cezaevi süreci sona erince bir dönem Adana'da sebze nakliyeciliği yapar, ardından Verem Savaş Derneği gibi çeşitli derneklerde çalışır ancak 1950 yılında Demokrat Parti iktidara gelince işine son verilir. Bu dönemde çeşitli dergilerde çıkan öyküleri ve basılan ilk romanı ilgi çektiği için, yaşamını kalemiyle kazanmak düşüncesiyle İstanbul'a gelir. İstanbul'da çeşitli dergilerde basılan öyküleri, kitapları ve yazdığı film senaryoları ile geçimini sağlamaya çalışır (Kudret, 2004: 321-322).

"Arka Sokak" adlı öykü kitabı ile hücre çalışması ve komünizm propagandası yaptığı gerekçesiyle iki kez tutuklanmıştır.

1970 yılında Bulgaristan'da yaşamını yitirir. Orhan Kemal, Kardeş Payı ve Önce Ekmek adlı öykü kitaplarıyla iki kez Sait Faik Hikâye Armağanı'nı $(1958,1969)$, yine Önce Ekmek adlı kitabıyla Türk Dil Kurumu Ödülü’nü (1969) kazandı. Ölümünden sonra, ailesi tarafından, “Orhan Kemal Roman Ödülü" (1971) kuruldu (Kudret, 2004: 321-322).

Orhan Kemal'in Baba Evi, Avare Yıllar, Cemile, Dünya Evi gibi biyografik romanları "Küçük Adamın Notları" başlığı altında toplanır. Orhan Kemal öykülerinde ve romanlarında içinde yaşadığı, yakından tanıdığı çevreleri ele almıştır (Kudret, 2004: 347).

Orhan Kemal yapıtlarını toplumcu gerçekçilik doğrultusunda oluşturmuştur. Toplumcu gerçekçilere göre sanatın yansıttığı gerçeklik toplumsal gerçekliktir. Bu gerçeklik devrimci gelişme içinde görülür ve doğru olarak tarihi somutlukla, işçi sınıfının eğitimi gözetilerek yansıtılır (Moran, 2011: 53). 
Toplumcu gerçekçilerin gerçekçi yöntem üzerinde direnmelerinin bir nedeni de geniş emekçi sınıfına en uygun düşen yöntem sayılmasıydı (Moran, 2011: 63). İş̧̧i sınıfının dertlerini anlatan Orhan Kemal de yapıtlarında toplumsal gerçekliğin çizgisinden ayrılmamıştır.

Biçim olarak Ömer Seyfettin, konu olarak Sabahattin Ali geleneğini sürdüren ve geliştiren Orhan Kemal, romanlarını kaleme aldığı 1949-1970 yılları arasındaki 21 yıllık sürede; sosyal gerçekçilikten, eleştirel sosyal gerçekçiliğe aşamalı olarak dönüşüm yaşar. Eserlerinde sosyal gerçekçilik ve eleştirel sosyal gerçekçilikle, romantik-psikolojik gerçekçilik unsurları iç içedir. Bu tavır, bütün sanat hayatını kapsayan sürekli ve belirgin bir çizgi halinde devam eder (Eliuz, 2009: 1136).

\section{Romanın Özeti}

Roman kahramanının ismi belirtilmemektedir. Romanda geçen olaylar roman kahramanının aile ve arkadaş çevresinde gerçekleşir. Mekân olarak Adana ve İstanbul kullanılmıştır. Kahraman Adana'da babaannesi ile yaşamaktadır. Annesi, babası ve kardeşleri önceleri Beyrut'tadır, ardından Kudüs'e geçmişlerdir. Bir zamanlar bolluk içerisinde yaşayan aile, babanın siyasi olaylara karışması nedeniyle sürgün hayatı yaşamaktadır. Babanın ülkeden ve işlerden uzak kalması aileyi ekonomik bir darboğaza sokmuştur. Roman kahramanımız yaşamın yükünü ve acısını sırtında taşımaktadır. Varlıklı bir yaşamdan geçim sıkıntısı içine düşen kahramanımız yaşama tutunmaya çalışmaktadır.

Roman kahramanı gencin Hasan Hüseyin ve Gazi adında iki yakın arkadaşı vardır. Arkadaşları ile sigara içip okuldan kaçmayı adet edinir. Okula gidiyorum diyerek evden ayrılan genç kahveye gider, kahvede gününü geçirdikten sonra eve döner. Futbol oynamak, koşmak bu gençlerin hem en büyük zevklerinden biri hem de kazanç kapılarıdır. Spordan aldıkları ufak paraları harçlık ederler. Giritli Kahvesi gençlerin okuldan kaçarak gittiği kahvedir. Kahvenin karşısındaki buğday tarlası içindeki kırmızı kiremitli evin kızları gençlerin sevgilileridir.

Roman kahramanı genç ve Gazi, okulu bırakarak İstanbul'a gitme düşleri kurarlar. Ancak bu düşlerini gerçekleştirebilmek için paraya gereksinim duymaktadırlar. Bu amaçla bir işe girip çalışmak isterler ve bir dokuma fabrikasında iş bulurlar. Önce işi öğrenmeleri ve sınavdan geçmeleri gereklidir. İşi öğrenip sınavı kazanınca çalışmaya başlayacaklardır. Bir gün bir iş kazasınatanıklık ederler. Dokuma işinde daha önce çalışanlara iş kazalarını sorarlar. Bu kazanın insanı öldürebileceğini öğrenince işten çıkarlar.

Babaanne gencin başıboş davranışlarına çözüm bulmak amacıyla halasının yanına yollamak ister. Aile gencin öğrenimini tamamlaması için tüm gücü ile mücadele etmektedir. Gencin halasına mektup yazan babaanneye olumlu cevap gelir. Yol harcamaları için gereken parayı yollayan hala, gencin zaman kaybetmeden yola çıkmasını istemektedir. Gencin arkadaşı Gazi, gencin halasının 
gönderdiği paranın kendilerine yeteceğini söyleyerek onun aklını çeler. Sevgilileri ile vedalaşarak İstanbul'a çalışmaya gideceklerini söylerler, geleceğe ilişkin planlarını paylaşırlar. Hasan Hüseyin'e haber vermeden İstanbul vapuruna binerler. Vapurda Zümrüt adında bir bayan ve ailesi ile tanışırlar. Kadın, roman kahramanı gence ve Gazi'ye iyi davranır. Ne isterlerse yapar. Gazi ne zaman açım dese kadın hemen sofrayı açar. Gazi, kadının genç ve güzel kızından hoşlanır. Birkaç günü mutlu geçirirler. Kadın ve ailesi portakal bahçelerinin olduğu şirin bir ilçede inerler. Kadının gidişine üzülürler. Yolculukta paraları bitince yük indirip bindirme işinde çalışılar. Yolda karşılaştıkları Hasan'la arkadaş olurlar. Hasan'ın kömür işçisi arkadaşı Nevzat İstanbul'da roman kahramanı gence ve Gazi'ye destek olur. Gençler İstanbul'da dolaşırken Aksaray'da bir muhallebicinin önünde Kasafan Cemal'e rastlarlar. Kasafan Cemal'le birlikte eski arkadaşları Yirmialtılık'ın yanına giderler. Paraları iyice azalmıştır. Yirmialtılık, bir lokantada çalışmaktadır. Beykoz yakınlarında bir ayakkabı fabrikası vardır. Bu fabrikanın ustaları öğle arası Yirmialtııı'ın çalıştığı lokantaya gelmektedir. Yirmialtılık ve patronu aracılı̆ııla bu fabrikada iş bulmayı düşlerler. Ancak hiç de umdukları gibi karşılanmazlar. Yirmialtılık, patronu ile konuşmayı bile istemez. Lokantanın tavan arasında birkaç gün kalırlar. Yirmialtılık'ın patronu kızınca Yirmialtılık'tan vapur parası isteyip oradan ayrılırlar ardından Nevzat'ın yanına giderler. Nevzat zor durumda kalan kahramanın ve Gazi'nin karınlarını doyurur. Beyazıt'ta açlık içinde otururken Giritli Kahvesi'nden arkadaşları Necip'i anımsarlar ve aramaya koyulurlar. Haliç Feneri'nde olduğunu anımsadıkları Necip'e ulaşırlar. Necip arkadaşlarını evinde bir gece güzelce misafir eder.

Gazi ve genç iş ararlar ancak bulamazlar. Çaresiz Adana'ya dönerler. Döndüklerinde Gazi babasından, genç de babaannesinden fırça yer. Babası Gazi'yi çalışması için dayısının yanına gönderir. İki gencin döndüklerinde aldıkları ilk haber sevgililerinin başkaları ile olduklarıdır, ikincisi ise kahvecinin tutuklandığıdır. Roman kahramanı gencin Adana'ya dönmesinin ardından gencin annesi Adana'ya gelmiştir. Annesi gence okuyarak bir baltaya sap olması konusunda öğütlerde bulunur. Annenin geliş amacı ekonomiktir. Kudüs'te işler yolunda gitmemektedir. Ekonomik olarak sıkıntı içinde olan ailenin paraya gereksinimi vardır. Roman kahramanı gencin erkek kardeşi Niyazi, Kudüs'te zorlu koşullar altında işportacılık yapmaktadır. Annesi bir zamanlar kendilerinin olan ve haksızca ellerinden alınan bir araziyi geri almaya çalışır. Mahkemeye başvurur, dilekçeler yazar ancak çabaları sonuçsuz kalır. Daha önce aynı arazi için babaanne de mücadele etmiştir ve başarılı olamamıştır. Ekonomik sıkıntı çeken aile artık yiyecek bulamaz konuma gelmiştir. Aç uyudukları bir gecenin sabahı anne borç istemek için eski bir dostun kapısını çalar. Ancak aldığı cevapla derin üzüntüler yaşar. Eski dost borç vermediği gibi roman kahramanının babasının yaptıklarını eleştirerek dostluğunu bitirdiğini söyler ve kapıyı kapatır. Anne baygın durumda eve gelir. Yaşanan olaylardan sonra roman kahramanı gencin okulla arası iyice açılır, okula isteksizce gider. Sonrasında ailesi yoksulluk içindeyken, okula 
gitmenin gereksiz olduğunu düşünerek okulu bırakır. Annesinin de yönlendirmesiyle başıboş kalan arazilerle ilgilenmek üzere köye gider.

Köye gittiğinde babasının bir arkadaşıyla karşılaşır, bir gece onlarda misafir olur. Ev halkına kendini olduğundan farklı gösterir. Evin kızına yakınlık duyar, kız olumsuz karşılık verince evi terk eder. Arazilerine sahip çıkmak için gittiği köyden eli boş döner. Annesi ve kız kardeşleri, babasının yanına döner.

Roman kahramanının kahvede tanıştığı İzzet Usta bilge bir kişidir, ona yol gösterir. Roman kahramanı genç fabrikaya muhasebe memuru olarak işe girer. İşe girdiği fabrikada bir iş̧̧i kızına âşık olur. Her gün onu takip eder ve evlerinin önünde onu bekler. Kızın on dört yaşında ve Boşnak kökenli olduğunu öğrenir. Ardından kızın da kendini sevdiğini duyar. Boşnak kız kendisini babasından istemesini söyler. Roman kahramanı babaannesine evlenmek istediğini belirtir. Romanın kahramanı gencin evlenmek istediği kızın bir fabrika işçisi olduğunu duyan babaanne, bu duruma karşı çıkar, ancak kahraman kararlıdır.

Roman, kahramanın evliliği ile biter. Aile şanına gölge düşürmek istemeyen babaanne, ödünç aldığı takılar ve eşyalarla düğünü yapar. Düğün sonunda ödünç eşyalar geri verilir. Elmas küpeleri çok sevmesine karşın eşyaların verilmesine üzülmediğini belirten Boşnak kız güçlü bir karakterdir. Roman çarpıcı cümlelerle son bulur:

"Aldırma kocacığım" dedi, "herkes sakız çiğner ama Çingene kızı tadını çıkarır... Değil mi?"

Dünyanın tadını çıkarmaya devam ettik (Kemal, 2005: 128).

Her türlü güçlüğe karşı mutlu olmaya çalışan bir grup insanın yaşantısı romana başarı ile aktarılmıştır.

\section{Romanda Geçen Olaylar}

- Kahramanın arkadaşları ile okuldan kaçarak kahveye gitmesi, futbol oynaması, sevgilisiyle ile buluşması.

- Roman kahramanı ve Gazi'nin okulu bırakması.

- Gazi ile roman kahramanı gencin fabrikada iş̧̧i olarak çalışmaları.

- Bir işçinin yaralanması olayına tanıkık etmeleri sonucu işi bırakmaları.

- Babaannenin roman kahramanını İstanbul'a halasının yanına göndermek için girişimde bulunması.

- Roman kahramanının haladan gelen parayla Gazi ile birlikte İstanbul’a gitmesi.

- Roman kahramanı ve Gazi'nin İstanbul'da yaşadığı yokluk ve işsizlik.

- Roman kahramanı ve Gazi'nin Adana'ya dönüşü. 
- Roman kahramanı ve Gazi'nin sevgililerinin gençleri terk etmesi.

- Roman kahramanının annesinin Adana'ya gelişi.

- Roman kahramanının okula dönüşü.

- Roman kahramanının annesinin arazileriyle ilgili hakkını arama çabaları ve çabalarının olumsuz sonuçlanması.

- Roman kahramanının ailesinin yaşadığı ekonomik sıkıntılar karşısında bunalıma düşerek okulu bırakması.

- Arazi işleri için doğduğu köye giden roman kahramanının elleri boş dönmesi.

- Roman kahramanının çeşitli işlerde çalışması.

- Roman kahramanının fabrikaya muhasebe memuru olarak işe girmesi.

- Roman kahramanının fabrikada gördüğü Boşnak kıza âşık olması.

- Roman kahramanının Boşnak kızı her gün iş çıkışı izlemesi, evine kadar takip etmesi.

- Boşnak kızın arkadaşı Güllü’nün roman kahramanını kızın peşini bırakması konusunda uyarması.

- Boşnak kızın roman kahramanına kendisini istetmesi için haber yollaması.

- Roman kahramanının durumu babaannesine açması.

- Boşnak, işçi kızla evlenme isteğinin babaannesi tarafından kabul edilmemesi.

- Roman kahramanın, kızı babaannesi olmadan istemesi.

- Roman kahramanının kararlıı̆̆ı sonucu evliliğin gerçekleşmesi.

- Düğün sırasında çokça eşya ve takının gelmesi.

- Gelen eşya ve takıların ödünç olduğunun öğrenilerek geri verilmesi.

- Tüm olumsuzluklara ve zorlu koşullara karşın roman kahramanı ve Boşnak kızın birbirine destek olarak yaşama tutunmaları.

Romanda geçen olaylar yukarıda belirtildiği gibidir. Olay örgüsünde kullanılan düğümler başarı ile kurgulanmıştır. Merak öğesi canlı tutulmuştur, rastlantısalığa yer verilmemiştir.

Edebi yapıtların işlevlerinden biri de insanın kendisiyle, başka insanlarla, doğal ve toplumsal çevresiyle çatışmalarını yansıtmaktır (Kavcar, 1999: 6). Roman çatışmalar açısından başarılı bir biçimde kurgulanmıştır. Yapıtta roman kahramanı yokluğun yaşattığı zorluklar ve varlıktan yokluğa düşmenin yaşattığı baskı nedeniyle kendi ile çatışma yaşar. Okulu bırakma ve istediği kızla evlenme konusunda ise ailesi ile karşı karşıya gelerek çatışma yaşar.

Babasının sürgün yaşamı sonucu yaşantısı değişen kahramanın yapıtın belli bölümlerinde "kişi toplum" çatışması yaşadığı görülmektedir.

\section{Romanın Konusu}

Romandageçim sıkıntısı çeken insanların verdiği yaşam mücadelesi anlatılmaktadır. Orhan Kemal iyi bildiği Güney Anadolu Bölgesi insanlarının sorunlarına eğilmiştir. Orhan Kemal karakterlerini 
daha çok Adana'daki fabrika iş̧̧ileri, küçük memurlar, ırgatlar arasından seçmektedir. Orhan Kemal mimetic bir yazardır, yani kendisinin tanık olduğu ya da olabileceği bir yaşamı, okurun da rahatça inanabileceği sıradan kişiler ve günlük olaylarla yansıtır (Moran, 2004/a: 101).

Tahir Alangu, Orhan Kemal'in romanlarını üç bölüme ayırmıştır:

\section{1- Otobiyografik romanlar.}

2- Adana ve Çukurova'da fabrika ve tarımda çalışan emekçilerin dünyasını anlatan romanlar.

3- İstanbul'da küçük adamların yaşamını sergileyen romanlar(Akt. Moran, 2004/a: 75).

Emek sorunlarını, iş̧̧i evrenini romana en iyi yansıtan yazar Orhan Kemal'dir (Çavdar, 2007: 64). Bu durumun nedeni yazarın uzun süre işçi sınıfının içerisinde yaşaması, yaşamı boyunca ekonomik mücadele vermiş olmasıdır. Avare Yıllar adlı romanda yazarın bu başarısını görmek olasıdır.

Her ne kadar Orhan Kemal'in eserleri Adana'da toprak ve fabrika işçilerinin romanları, İstanbul'da küçük adamların yaşamları olmak üzere gruplandırılabilse de aslında Orhan Kemal tek eser yazmıştır. Eserlerinin her biri bu büyük ve geniş eserin ayrı bölümleri durumundadır (Aktaş, 1990: 43-44).

Orhan Kemal 1960'ta Türk köylerinden kentlere akımı ilk kez konu yapmış Türk romancılarındandır. Dahası, iktisadi çöküntü yıllarında bu sürecin tersine döndügünü de gözlemiş ve bu kez kentten köylere, pamuk tarlalarına koşan ailelerin dramını da anlatmıştır (Timur, 2002: 165). Aynı zamanda Orhan Kemal kentte varoşlara yerleşen kırsal kökenlilerin varoşlardaki yaşayışını da yapıtlarına konu etmiştir (Çavdar, 2007: 183). Buradan yola çıkarak Orhan Kemal'in göç olgusunu çok boyutlu işlediğini söylemek mümkündür.

Yazar romanla vermek istediği ana fikir, yaşamın zorluklarına karşı mücadele etmenin ve içinde bulunduğumuz yaşam koşullarında mutlu olmanın gerekliliğidir.

\section{Roman Karakterleri}

\section{Roman kahramanı genç:}

a)Fiziksel durumu: Burnu kemerli, parmakları uzun ve incedir. Belirli dönemlerde çok zayıftır çünkü çok fazla açlık çekmiştir. Yapıt roman kahramanının ilk gençlik yıllarını kapsar.

b) Sosyal durumu: Roman kahramanı gencin adı belirtilmemiştir. Varlık içerisinden yokluğa düşmüş bir ailenin çocuğudur. Ayakkabılarının altı patlaktır, pantolonunun paçaları sökülmüştür. Yiyecek yemeği zor bulmaktadır. Roman kahramanının ailesi onun uzağındadır. Ailesi sürgün hayatı yaşamaktadır, yokluk içindedir. Roman kahramanının ailesinin eski çevresi, roman kahramanının 
babasını ailesini düşürdüğü durum nedeniyle suçlamaktadır. Kahraman futbol oynamayı sever, kimi zaman harçı̆ı̆ını futboldan çıkarır. Kahramanın okulla arası iyi değildir. Bu durumun temel nedeni yılgınlıktır, çünkü okula gitse de diploma alsa da hükümete karşı bir babanın oğlu olmanın iş kapılarının yüzüne kapanmasına neden olacağını düşünmektedir.

c) Psikolojik durumu: Roman kahramanı kendine güvenini yitirmiştir. Kendini işe yaramaz ve çirkin görmektedir. Zayıflı̆ı, kuru elleri ve eski kıyafetleri ile utanılası bir görünüş sergilediğini düşünmektedir. Ailesine yeteri kadar yardım edememek kahramanın içsel bir gerilim yaşamasına neden olmuştur. Yaşadığı zorluklar kahramanın içine kapanmasına ve çekingen bir kişiliğe bürünmesine yol açmıştır.

Gazi:

a) Fiziksel durumu: Roman kahramanı gibi zayıftır. Sigara tiryakisidir.

b) Sosyal durumu: Kahramanın yakın arkadaşlarındandır. Roman kahramanının İstanbul yolculuğuna çıktığı kişidir. Okulla arası iyi değildir.

c) Psikolojik durumu: Hayalperest bir kişiliğe sahiptir. Çapkın ve hovardadır.

\section{Babaanne:}

Sosyal durumu: Eski yaşantısının izleri üzerinde yaşamaktadır. Ekonomik sıkıntılar içerisinde torununa sahip çıkmaya çabalamaktadır.

\section{Roman kahramanının annesi:}

a) Fiziksel durumu: Saçlarına aklar düşmüştür.

b) Psikolojik ve sosyal durumu: Gururlu bir kişiliğe sahiptir. Yaşamın zorluklarla sınadığı bir annedir.

\section{Roman kahramanının babası:}

Sosyal durumu: Memleket meseleleri için kendisinin ve ailesinin yaşamını alt üst eden, bilge bir hukuk adamıdır.

\section{Hasan Hüseyin:}

a) Fiziksel durumu: Romanda fiziksel özelliği olarak cam gözlü oluşuna değinilir.

b) Sosyal durumu: Roman kahramanının yakın arkadaşlarından biridir. Muhasebeci olmak için çalışmaktadır. 
c) Psikolojik durum: Roman kahramanının en aklı başında arkadaşlarındandır, ona sağduyulu öğütler verir.

İzzet Usta:

a) Fiziksel durumu: Yapıtta İzzet Usta karakterinin fiziksel görünümüne ilişkin yalnızca mavi bir tulum giydiği bilgisi yer almaktadır.

b) Sosyal durumu: Roman kahramanı İzzet Usta'yla Gazi'yle kahvede tavla oynarlarken tanışmıştır. Eşini fabrika kazasında, kızını ise bir tren kazasında kaybetmiştir. Düzenli bir yaşamı yoktur, zaman zaman evden ve bulunduğu ortamdan uzaklara gitmektedir.

c) Psikolojik durumu: Roman kahramanına yol gösteren bilge bir kişiliktir.

\section{Boşnak Kız:}

a) Fiziksel durumu: 14 yaşlarında beyaz tenli güzel bir kızdır. Bir evi çekip çevirebilecek dayanıklılığa sahiptir.

b) Sosyal durumu: Roman kahramanının fabrikada görerek âşık olduğu iş̧̧i kızdır. Yoksul bir mahallede yaşarlar. Babası ve ağabeylerinin baskısı altında yaşamaktadır. Roman sonunda kahramanla evlenir.

c) Psikolojik durumu: Boşnak kızı karakteri kahramana yaşama sevinci aşılamaktadır. Roman kurgusu içinde zaman zaman çocuksu hareketler sergilemektedir.

Niyazi:

a) Fiziksel durumu: Roman kahramanının aksine esmer bir çocuktur.

b) Sosyal durumu: Ailesi ile Kudüs'te kalmıştır. Aile geçimini sağlamak için Kudüs'te işportacılık yapmaktadır.

Nevzat:

a) Fiziksel durumu: Beyaz dişlere ve gülümseyen bir yüze sahiptir.

b) Sosyal durumu: İstanbul'da kömür iş̧̧isi olarak çalışır. Gazi ve roman kahramanını odasında ağırlar.

c) Psikolojik durumu: İçen, samimi bir kişiliğe sahiptir.

\section{Dil ve Anlatım}

Eserin anlatım düzeni çok güçlü değildir. Olaylar ve durumlar ilgi çekici yönleri ile anlatılırken olay örgüsünde yer yer kopukluklar görülmektedir. Roman kahramanı genç ve arkadaşlarının 
sevgililerinden ayrılmaları ve İstanbul'a gitmeleri çok ani olmuştur, bu durum kurguda kopuklukların oluşmasına neden olmuştur. İlk gençlik döneminde yaşanan aşkların, ayrılıkların şiddeti düşünüldüğünde; söz konusu durumun kurguya aktarımının yetersiz olduğu görülür. Sevgililerinden ayrılarak İstanbul'a gelen gençler bir anda yaşam mücadelesi içine atılır. Gençlik döneminde yolları yaşam mücadelesiyle ayrılan arkadaşlardan romanın ilerleyen bölümlerinde bahsedilmez.

Yukarıda değinilen söz konusu kopukluklar anlatımın düzenini bozmaktadır ve anlam boşlukları oluşturmaktadır. Roman, kahramanın ağzından anlatılmaktadır.

Baba Evi ve Avare Yıllar tek karaktere yaslanan romanlardır ve okurun roman kahramanıyla özdeşleşmesi sonucu onun serüvenine duyacağı ilgidir romanı ayakta tutan. Bu romanda baba figürü arka planda kalmıştır. Bazen olumlu bazen olumsuz rol oynamaktadır. Baba oğul ilişkisi görüldüğünden daha karmaşıktır. Yapıttaki delikanlı kendisini, çevresini anlamak için, duygularını çözümlemek için çaba göstermez. Hep yüzeyde kalarak sürdürür yaşamını. Denilebilir ki o yaştaki bir çocuğun çevresindekileri ve kendini, içinde yaşadıkları olayları çözümlemesi beklenemezdi. Ama sorun olayları yaşayan kişinin henüz çocuk sayılacak yaşlarda olmasından değil, anlatıcının konusuna yaklaşımından kaynaklanmaktadır. Orhan Kemal'in otobiyografik romanlarında niçin yüzeyde kaldığını açıklamak için bu nokta üzerinde durulması gerek: Anlatımda iki ben vardır: anlatılan ben (olayları yaşayan ben), anlatıcı ben. Bunların arasındaki ilişki de çok çeşitli olabilir. Sözgelimi anı defteri biçiminde yazılmış romanlarda o andaki olayların anlatımı söz konusu olduğu için iki ben arasında yaş, olgunluk, anlayış ve kişilik bakımından ayrım yoktur. Ama geçmişi anlatan romanlarda zaman, anlatılan ben ile anlatıcı beni ayırır çünkü kişiler değişim geçirmişlerdir. Avare Yıllar adlı yapıtta anlatılan ben ile anlatıcı ben aynı düzeydedir. Bu durum "Orhan Kemal romanı anlatırken bu düzeydeydi." demek değildir. Kullandığı anlatııının bilinç düzeyi anlatılan kişi ile aynıdır. Bu düzey anlatıcı ben'in olaylara ve romanın diğer kişilerine anlayışlı ve çözümleyici bir bakışla yaklaşmasına engel olduğu için öyküde işlenebilecek, derinleşebilecek kişilikler, ilişkiler, sorunlar ve yaşanan aile dramı bir yana bırakılmış, tek karaktere yaslanan bir anılar dizisiyle yetinilmiştir. Avare Yıllar adlı romanı yazarken Orhan Kemal'in romancılığının çıraklık döneminde olduğu unutulmamalıdır (Moran, 2004/a: 77-81).

Moran'ın da belirttiği gibi Avare Yıllar adlı romanı dil ve anlatım açısından incelerken Orhan Kemal'in romancılı̆̆ın başlangıç döneminde olduğu unutulmamalıdır. Yapıtta görülen anlam boşlukları, anlatımda yer alan kopuklukların nedeni bu duruma bağlanabilir.

Romanda sade bir dil kullanılmıştır. Orhan Kemal'in eserlerindeki bu sade ve akıcı anlatım, ustalığının göstergesidir. Bununla birlikte onun "asıl kudreti, titiz çalışmasına rağmen rastgele ve özenilmeden yazılmış intibasını uyandırabilmesidir." (Bezirci, 1984: 132). Sıradan insanların, emekçi ve 
işçilerin yaşantılarının anlatıldığı Avare Yıllar'da anlatıcı kişi; günlük yaşantısındaki konuşmalarını özenmeden, rastgele kullanıyormuş gibi görünse de yazarın kitlenin üslubunu titizce inceleyerek, ustaca aktardığı görülür. Örneğin Göçmen Mahallesi'nde dolanan roman kahramanı gencin ağzından göçmenlerin yaşantıları, evleri, kültürleri, deyişleri kurgu içerisinde rastgele aktarılıyor gibi görünse de ardında titiz bir çalışma vardır.

Yapıtta genel olarak yabancı sözcükler kullanılmamıştır. Cümleler kısa ve anlaşııır biçimde oluşturulmuştur. Karşılıkı konuşmalara yer verilerek anlatımda zenginlik sağlanmış ve çoklu bakış açısı geliştirilmiştir. Ancak karşılıklı konuşmaların fazlalığı zaman zaman yapıtın anlatımını sıkıcı kılmaktadır.

Yazılarının diyaloglar üzerinden ilerlemesi ve mümkün olduğunca kendisini geri çekerek, yalnızca bir tanık ve aktarıcı rolünü üstlenmesi konusunda zaman zaman anlatılarının röportajdan farksız olduğu gibi nedenlerle eleştirilir (Hacısalihoğlu, 2008: 53).

Yerel ağızlar ve farkı kültürlerin konuşmalarına ilişkin örnekler başarı ile yansıtılmıştır.

... "Ne dineliyon, ne dineliyon, ne dineliyonlan! Yomiyeveriyok tekmil!"... (Kemal, 2005: 82).

... OooDervişa! Hodivâmodattineşkokajem! Evoevo. (OooDervişa, buraya gel sana bir şey söyleyeceğim, işte, işte...) (Kemal, 2005: 95).

Orhan Kemal'in eserlerinde Güney Anadolu ve kısmen diğer bölgelerin ağızlarından aldığı, günümüzde pek kullanılmayan bazı sözcükler dikkat çekmektedir (Pıtır, 2012: 19).

Bu duruma örnek olarak "Ben gördüm, vardı bir Süleyman, hallaçta çalışırdı, kabarık saçlı, Arapuşağı”" tümcesindeki "arapuşağı” sözcüğü gösterilebilir (Kemal, 2005: 113).

\section{Teknik}

Yazar karakterleri başarı ile işlemiştir. Karakterlerin geçirdiği değişim inandırıııdır. Eserde tahlil ve tasvirlere çok yer verilmemiştir. Yalın bir anlatım tercih edilmiştir. Olay kurgusundaki merak başarı ile yapılandırılmıştır. Yapıtın sonuna kadar merak öğesi canlı tutulmuştur.

Anadolu romanı yazarları (Yaşar Kemal, Orhan Kemal, Kemal Binbaşar, Fakir Baykurt) anlatacakları öyküye şekil vermek isterken, çoğu kez, destan, halk hikâyesi, masal ve efsane türlerinden yararlanmak eğilimindedirler. Bu eski anlatı türlerinde ise mitostan miras kalan etkili kalıpları buluruz. Bilerek ya da bilmeyerek bu mirastan yararlanan sözünü ettiğimiz yazarlar yapıtlarına yazınsal bir form kazandırmış oldular (Moran, 2004/b: 16).

Orhan Kemal'in Avare Yıllar adlı yapıtında Moran'ın da belirttiği gibi halk hikâyelerinin izleri görülmektedir. Örneğin, "Leyla ile Mecnun" adlı halk hikâyesinde Leyla'yı beğenmeyenlere 
Mecnun'un yanıtı: "Siz gelin onu bir de benim gözümle görün." olmuştur. Avare Yıllar adlı yapıtta da kahvedeki kişiler ve yakın çevredeki insanlar, roman kahramanı genç ve arkadaşlarını sevgilileri konusunda uyarsalar da onlar bu uyarılara kulak asmamışlardır. Kızlara duydukları aşk roman kahramanı genç ve arkadaşlarının gözlerini kör etmiştir.

\section{Sonuç ve Değerlendirme}

Sanatçıların toplum sorunlarını dile getirmesinin önemi düşünüldüğünde Orhan Kemal'in bu sorumluluğu başarı ile yerine getirdiği görülmektedir. Orhan Kemal; aydınlık, gerçekçi bakış açısıyla insan toplum ilişkilerini Avare Yıllar adlı yapıtta ustalıkla yansıtmıştır. İş̧ilerin yaşadığı sıkıntıları ve emekçilerin sorunlarını dile getirirken yazarın toplumla iç içe olması yapıtı başarılı kılmıştır. Yıllar öncesinin Anadolu esintilerinin tadı yapıtta başarı ile yansıtılmıştır.

Bu yapıt dönemin diğer yapıtlarıyla karşılaştırıldığında durum şöyledir:

Kemal Tahir'in Sağırdere romanında köyden sevdiği kıza kavuşamayarak ayrılan bir gencin şehre giderek yaşam mücadelesi vermesi, değişim yaşaması sonrasında köye dönmesi konu edilmiştir. Bu kurgu Avare Yıllar ile benzerlikler göstermektedir. Kemal Tahir'in Yediçınar Yaylası adlı yapıtında ise geleneksel halk hikâyeleri ve meddah anlatımından yararlandığı görülür. Halk hikâyelerinden yararlanma eğilimi Orhan Kemal'de de görülmektedir. Fakir Baykurt yapıtlarında Orhan Kemal gibi emekçinin, çiftçinin yaşantısını, çabasını konu edinmiştir. Orhan Kemal yapıtları Yaşar Kemal yapıtlarıyla ortak öğelere sahiptir. Orhan Kemal ve Yaşar Kemal mekân olarak genellikle Çukurova, Adana yöresini kullanmışlardır. İş̧iler, toprak emekçilerini konu olarak seçmişlerdir. Avare Yıllar adlı yapıtta da bu durum örneklenmektedir.

Günümüzde sinema ve televizyon endüstrisinde sıklıkla yer alan Orhan Kemal yapıtlarının ilgi görmesinin nedeni olay örgüsündeki başarı ve halkın sorunlarının, hayallerinin, beklentilerinin halk diliyle dile getirilmiş olmasıdır. Yapıtlarında ezilenin yanında olan Orhan Kemal, ekonomik sıkıntı çektiğini bilen yayınevleri tarafından yaşamı boyunca sömürülmüştür.

\section{Kaynakça}

Aktaş, Ş. (1990). Orhan Kemal (1914-1970). Türk Dili Dil ve Edebiyat Dergisi. c. 1990/II. S. 463. s. 33-45.

Bezirci, A. (1984). Orhan Kemal. İstanbul: Tekin Yayınevi.

Çavdar, T. (2007). Türkiye'nin yüzyılına romanın tanıklığı. İstanbul: Yazılama Yayınevi.

Eliuz, Ü.(2009). Orhan Kemal'in romanlarında bakış açısı ve anlatııı. Turkish Studies. Volume 4/8 Fall 2009. s.1134-1165.

Hacısalihoğlu, E. (2008). 1945-1960 döneminde Türkiye'de çalışma yaşamının Orhan Kemal romanlarında temsili. İstanbul: Marmara Üniversitesi Sosyal Bilimler Enstitüsü, Çalışma Ekonomisi ve Endüstri ilişkileri Anabilim Dalı, Çalışma Ekonomisi Bilim Dalı, Yüksek Lisans Tezi.

Kavcar, C. (1999). Edebiyat ve eğitim. Ankara: Engin Yayınevi. 
Kemal, O. (2005). Avare yıllar. İstanbul: Epsilon Yayıncılık.

Kudret, C. (2004). Türk edebiyatında hikâye ve roman 3. İstanbul: Dünya Yayıncılık.

Moran, B. (2004/a). Türk romanına eleştirel bir bakış 2. İstanbul: İletişim Yayınları.

Moran, B. (2004/b). Türk romanına eleştirel bir bakış 3. İstanbul: İletişim Yayınları.

Moran, B. (2011). Edebiyat kuramları ve eleştiri. İstanbul: İletişim Yayınları.

Pıtır, Z. (2012). Orhan Kemal'in eserlerinde folklorik unsurlar. Niğde Üniversitesi Sosyal Bilimler Enstitüsü, Türk Dili ve Edebiyatı Anabilim Dalı, Türk Dili ve Edebiyatı Bilim Dalı, Yüksek Lisans Tezi.

Taner, T. (2002). Osmanlı-Türk romanında tarih, toplum ve kimlik. Ankara: İmge Kitabevi. 